\section{Gyrfalcon (Falco rusticolus)}

\section{Record for Saskatchewan}

By A. F. Oeming, Edmonton

On 11 October, 1957, my friend John Matthew's of Edmonton while on a goose shoot near Luseland, Saskatchewan, observed an American hunter down a large falcon. The bird had stooped down on some ducks that were feeding near the hunter's goose decoys.. Matthews was unable to observe the killing through his binoculars and upon walking to the scene of the killing he discovered the dead bird. to be a large immatureplumaged female Gyrfalicon. The bird was of slate grey coloration and weighed 57 ozs. In weight, color and age it was identical to the Gyrfalcon shot near Whitford Lake, Alberta, the previous fall.

INFORMATION WANTED-The writer would appreciate informaticn on this species from anyone who has seen them during the fall and winter in Saskatchewan. Data as to color, location and activity at time of observation would be most appreciated. Of special interest would be any report of such a bird repeatedly seen in a particular area. Send information to Albert $F$. Oeming, Edmonton Zoological Society, Rm. 6, 10126-100 Street, Edmonton,

\title{
Prairie Falcon Nesting Records in Sask.
}

By Richard W. Fyfe, Saskatchewan Museum of Natural Hisitory

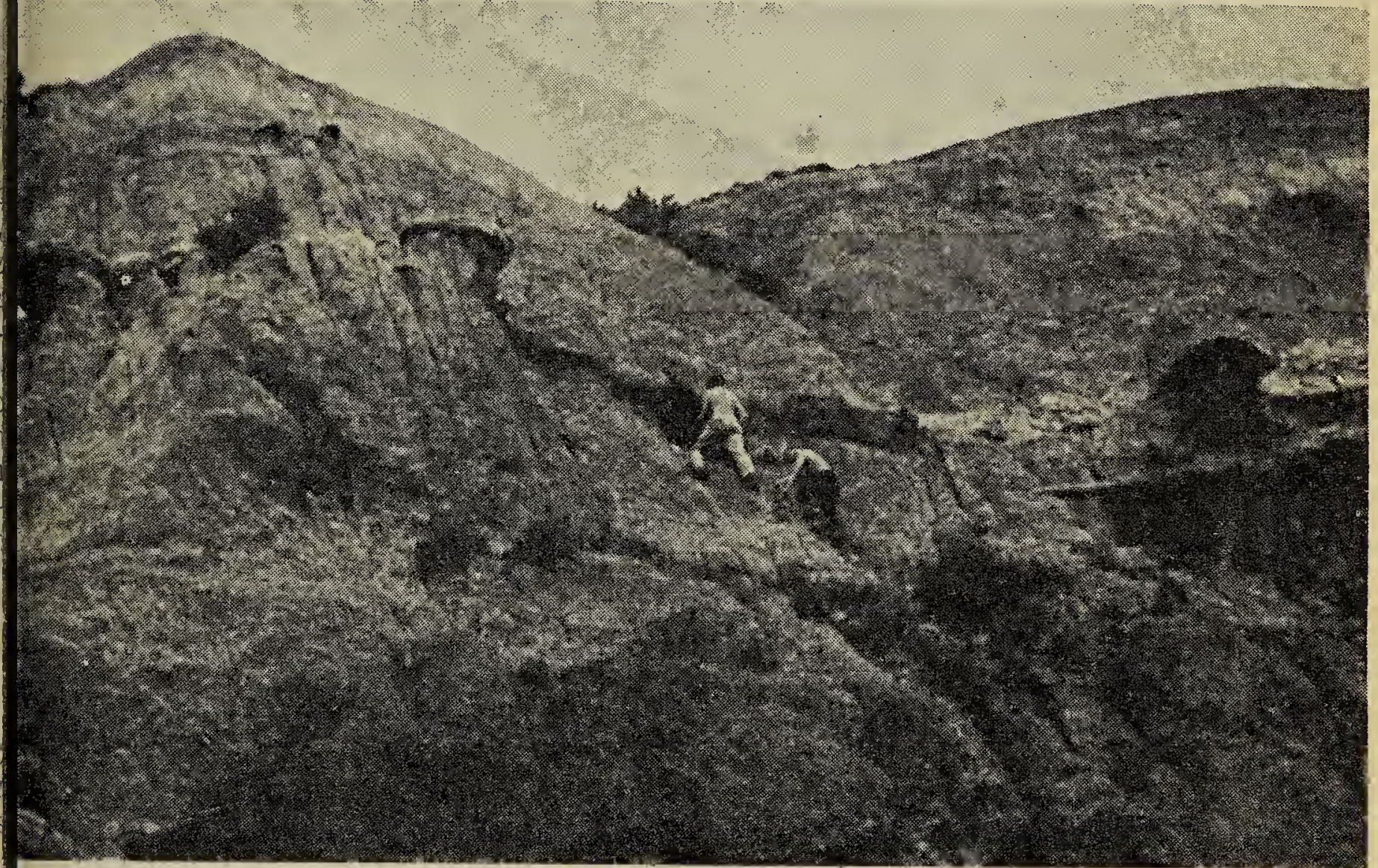

Photo by R. W. Fyfe Willoway examining Prairie Falco
the valley floor at the Big Muddy.

The first and only reported nestng of Prairie Falcons (Falco mexianus) in Saskatchewan is that of a et of four eggs collected at Battle reek (which flow's from the Cypress Hills) by J. E. Bowman on May 3, 91.4 (Godfrey, 1950. Birds of the yypress Hills and Flotten Lake Reions Saskatchewan). To the preent time no further nest records have been recorded although these birds are occasionally seen and are listed as occurring in this province (Taverner, 1945, Birds of Canada; Bent, 1938, Life Histories of North American Birds of Prey).

On July 1, 1958, in Big Muddy Valley, three nest sites of Prairie Falcons were found by Waiter Knudsen, Chris Willoway and myself. All three 


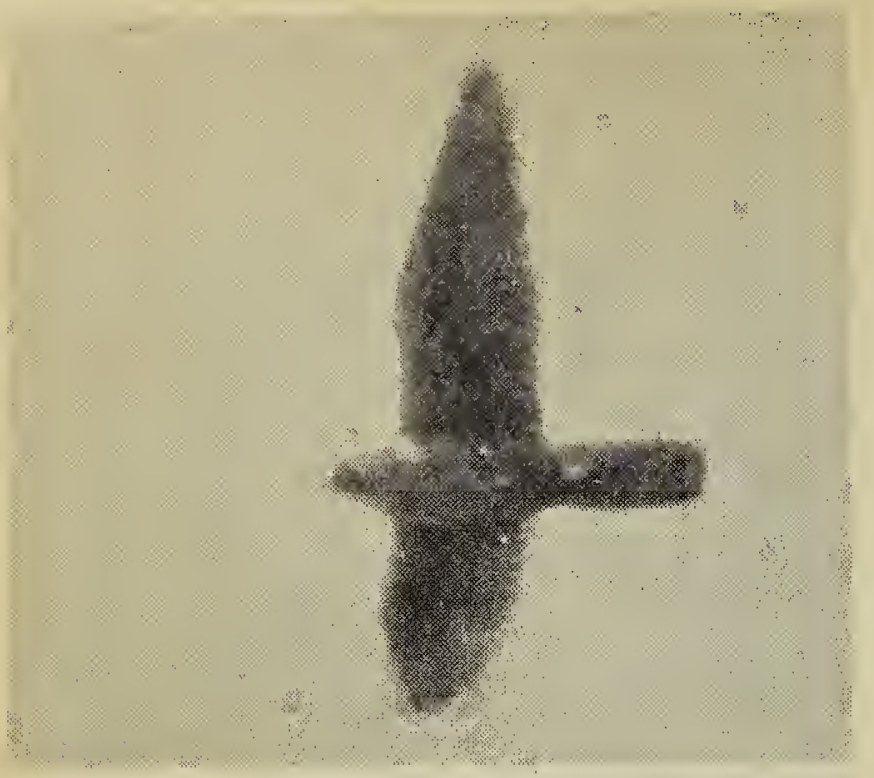

\section{Photo by R. W. Fyfe Prairie Falcon.}

aeries were located within a distance of one mile which would indicate that these birds nest regularly where suitable locations may be found in this valley. It was relatively easy to locate the aeries because they were marked by "whitewash" and because the enraged parents came as much as one half mile to meet us and screamed overhead until we left. Two nests containing three young each were found on the sides of the 300 -foot mud and shale cliffs in the valley, approximately 280 feet above the valley floor. The third was located on a somewhat lower cliff estimated at about 100 feet, the nest cavity being some 14 to 20 . feet below the top; two young were observed perched at the enitrance. All three aeries faced south or south-east and were in large cavities on the steepest sides of the cliffs. Two of the nests were inspected at close range but the third was considered out of reach. The cavities which were examined were large and apparently naturally formed, the first being approximately 6 feet in diameter and extending 5 to 6 feet into the face of the cliff: the second, although only $2 \frac{1 / 2}{2}$ to 3 feet in diameter, was about 10 feet in depth. No nesting material was present and only a small amount of debris from past meals was found.
Two additional active aeries hav been found and checked: one wit at least two young was found sout of Beechy in the South Saskatchewa River Valley by Tom Gentles in Jun of this year and verified by mysel on July 5 ; an additional nest in th Big Muddy'Valley was found an identified by three boys and myse on July 12, 1958.

Both of the above nests were als found on southern exposures and i rather large natural cavities. Litte was found in each, although no riest ing material was present, and eac was well marked by "whitewash" a the entrance of the cavities. The aeri heights varied somewhat from th others: the one found south o Beechy was approximately 50 feet is height on a 75 foot cliff; the on found in the Big Muddy Valley of July 12 was approximately 150 fee up the side of a 200-foot cutbank.

An additional nest site which wa probably that of a Prairie Falco was found vacated in June in th South Saskatchewan River Valle. south-west of Glidden. Smal feathers were seen near the entranc while below this and the adjacen ledge "whitewash" was present. Fur. ther down the cliff a wing feather 0 a Prairie Falcon was found. While we were attempting to reach the site : Prairie:Falcon came to the area an circled above us but did not exhibi the concern shown by the other birds when we were near their young. We suspect a possible early nesting of the birds at this nest. However, further check will be made in the coming year to determine whethes this is a used aerie.

Any additional nesting records of Prairie Falcon are valuable as each. is a verification or extension of the known breeding range in Canada However, I would warn against the examination of new nests until mir or late June. Prairie Falcons may leave their eggs if disturbed for too long a period early in the nestinf season, but if left undisturbed, the birds will use one aerie for many years.

\section{Protection of Birds of Prey To Be Discussed at Annual Meeting, Saskatoon, October 18th}

If you are interested in the protection of birds of prey in Saskatchewan, plan to attend the SNHS ANNUAL MEETING, OCTOBER 18, in SASKATOON. If unable to attend the meeting, please send us a letter in support of a resolution for protection. 